\title{
Palladium-Catalyzed Conversion of Aryl Triflates to Aryl Fluorides
}

Synthesis

Key words

aryl triflates

aryl fluorides

palladium
$t$-BuBrettPhos (6 mol\%)<smiles></smiles>
$\underset{\mathrm{PhMe}, 80-130^{\circ} \mathrm{C}, 12 \mathrm{~h}}{\stackrel{\left[(\text { cinnamyl } \mathrm{PdCl}]_{2}(2 \mathrm{~mol} \%)\right.}{\longrightarrow}}$

$\mathrm{R}=\mathrm{Alk}, \mathrm{Ar}$, ketones, esters, amines, ethers, nitro

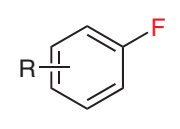

up to $85 \%$ yield

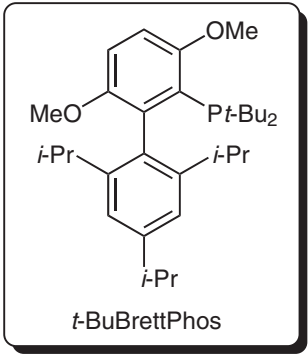

Selected examples:<smiles>CC(=O)c1cc(C)c(F)c(C)c1</smiles>

$110^{\circ} \mathrm{C}, 83 \%$ yield<smiles>CC(C)(C)OC(=O)c1ccc(F)cc1</smiles>

$80^{\circ} \mathrm{C}, 85 \%$ yield (10 mmol scale)<smiles>O=c1cc(-c2ccccc2)oc2cc(F)ccc12</smiles>

$80^{\circ} \mathrm{C}, 63 \%$ yield<smiles>C=CC1CN2CCC1C2C(OC(C)=O)c1ccnc2ccc(F)cc12</smiles>

$110{ }^{\circ} \mathrm{C}, 70 \%$ yield<smiles>CN(C)c1cccc(F)c1</smiles>

$130^{\circ} \mathrm{C}, 84 \%$ yield<smiles>[BH3-]</smiles><smiles>Fc1ccccc1</smiles>

Boc

$110{ }^{\circ} \mathrm{C}, 73 \%$ yield

$130{ }^{\circ} \mathrm{C}, 57 \%$ yield
Significance: The biaryl phosphine ligand $t$-BuBrettPhos in combination with [(cinnamyl) $\mathrm{PdCl}]_{2}$ is shown to catalyze the fluorination of aromatic and heteroaromatic triflates using CsF as fluorine source. This reaction proceeds under relatively mild conditions and with high functional group tolerance.
Comment: In a few cases, regioisomeric products are observed, but the overall yields remain high. The success of the reaction crucially depends on the sterically demanding $t$-BuBrettPhos ligand, since it prevents the formation of dimeric $[\mathrm{LPdAr}(\mathrm{F})]_{2}$, but also promotes reductive elimination of the Ar-F bond due to its large size. This method can be expected to be applicable for the preparation of biologically active aryl fluorides. 